\title{
GÜVENLIKK İKLIMİ ALGISININ DEMOGRAFİK FAKTÖRLERE GÖRE ALAN KURAMI BAĞLAMINDA İNCELENMESİ: İNŞAAT SEKTÖRÜNDE BİR UYGULAMA
}

\author{
EXAMINING PERCEIVED SAFETY CLIMATE BY DEMOGRAPHIC FACTORS IN \\ THE CONTEXT OF FIELD THEORY: AN APPLICATION IN CONSTRUCTION \\ INDUSTRY
}

\author{
Samet KILIÇ ${ }^{1}$ - Pınar ACAR ${ }^{2}$
}

Öz

Günümüz küresel çevresinde ve yerel bağlamda Türkiye'de, inşaat sektöründe çalışan işgörenlerin güvenlik ve sağlığıyla ilgili sorunların artması araştırmamızın sorunsalının temel odağını oluşturmuştur. İş sağlığı ve güvenliğinin örgüt içinde kurulan değerler sistemiyle yakından ilişkili olmasından dolayı, bir iş yerinde sadece kuralların yazılması ve uygulamaya konulması tek başına yeterli olmamaktadır. Aynı zamanda tüm çalışanların ve yöneticilerin dahil olacağı bir güven ikliminin tesis edilmesi ve bu iklimin örgüt kültürü ile uyumlu hale getirilmesi oldukça önemlidir. Araştırmamızın temel varsayımı Kurt Lewin'in Alan Teorisi ile desteklenmiştir. Bu çalışmada nicel araştırma yöntemi kullanılmıştır. Konu kapsamında teorik çerçevenin çizilmesinin ardından 79 beyaz yakalı çalışan ile gerçekleştirilen uygulamada, katılımcıların güvenlik iklimi algılarının çeşitli demografik faktörlere (cinsiyet, eğitim vs) göre farklılık gösterip göstermediği incelenmiştir. Araştırmanın verileri SPSS 20 programı kullanılarak analiz edilmiştir. Araştırmada kullanılan ANOVA ve t-test analizleri sonucu ortaya çıkan bulgular, inşaat sektöründe görev yapan çalışanların güvenlik iklimi algılarının, çalıştıkları sektöre ve pozisyonlarına göre değişmekte olduğunu ortaya koymuştur.

Anahtar kelimeler: Güvenlik iklimi, örgüt kültürü, örgüt iklimi, iş sağlı̆̆ı.

\begin{abstract}
Nowadays, both in global and local context especially in Turkey, the problems related to the safety and health of employees working in the construction industry has been the basis of our research problem. As occupational health and safety is closely related to the system of values established within the organization, it is not sufficient to write and implement rules only in a workplace. It is also important to establish a climate of trust that will involve all employees and managers, and to bring this climate into line with the organizational culture. The main assumption of our research was supported by Kurt Lewin's Field Theory. In this study, quantitative research method was used. Within the scope of the study, 79 white-collar employees performed the theoretical framework and examined whether the perceptions of the security climate differ according to various demographic factors (gender, education etc.). Data were analyzed using SPSS 20 program. The results of ANOVA and t-test analyzes used in the study revealed that the safety climate perceptions of the employees working in the construction sector are changing according to the sector and positions they work in.
\end{abstract}

Keywords: Security climate, organizational culture, organizational climate, occupational health.

\footnotetext{
${ }^{1}$ Bahçeşehir Üniversitesi, Sosyal Bilimler Enstitüsü, smtklc@ gmail.com, Orcid: 0000-0003-1943-811X

${ }^{2}$ Dr. Öğr.Üyesi, Beykoz Üniversitesi, İşletme ve Yönetim Bilimleri Fakültesi, pinaracar@beykoz.edu.tr, Orcid:0000-0002-4290-6383
} 


\section{GİRIŞ}

Örgütlerin güvenli iş ortamı ve koşullarına sahip olmaları; işgörenlerin verimlilikleri, performansları ve aidiyet duygusu gibi kazanımlar açısından büyük önem taşımaktadır. Güvenliğe atfedilen değerler, ona dair geliştirilen kriter ve normlar ile uygulamaya konulan hususlar ve prosedürler, paylaşılmakta olan unsurlarda pozitif alg1 meydana getirir. Bu sayede de; işgörenler, çalışma ortamlarındaki risklerle alakalı fikir ve görüşlerini beyan ederek, önerilerde bulunurlar. Neticede işverenin sözü edilen riskli hususların denetilmesiyle alakalı algıların seviyesinin geliştirilmesi ve işgörenlerin bu yönde davranışlar sergilemesi Güvenlik İklimi olarak ifade edilebilir. Bir örgütte güvenliğe dair bir çalışma ikliminin meydana getirilmesi ve buna paralel olarak iş kazalarının ve meslek hastalıklarının önüne geçilmesi için birtakım önlemlerin alınması gerekli ve zaruri bir faaliyettir.

Dünyanın pek çok yerinde olduğu gibi ülkemizde de iş kazası ve meslek hastalığı denildiğinde akla gelen ilk iş kollarından biri inşaat sektörü olmaktadır. Bu durumun temel sebebi, söz konusu sektörün kendine has iş koşullarının olması ve sektördeki bilinçliliğin henüz istenen seviyede olmamasıdır. İnşaat sektöründeki risklerin bir diğer nedeni ise sektörde uygulamaya konulan her bir projenin birbirinden farklı olması ve bu nedenle yapılan her yapının inşa sürecinde çalışanlara sağlanan koşulların değişmesidir. Nihayetinde her proje farklı risklere sahip olmakta ve çalışanlara standartlaşmış bir çalışma ortamı sunulamamaktadir.

İşletmelerde güven algısının tesis edilmesi, çalışanların kurumlarına, iş koşullarına, yöneticilerine güven duyarak işlerini yerine getirmesi pek çok faktörle birlikte iş sağlığ 1 ve güvenliği ile de yakın ilişki içerisindedir. Çoğu ülkede olduğu gibi ülkemizde de iş sağlığ ve güvenliği kanunlar ile çerçevelenmiştir. Kanunların da işaret ettiği biçimde, örgütlerin işgörenlerine karşı birtakım sorumlulukları vardır ve bu sorumlulukların yerine getirilmesinin güven ikliminin oluşmasına katkıda bulunacağ 1 açıktır.

$\mathrm{Bu}$ araştırma Gestalt kuramcılarından Kurt Lewin'in Alan Teorisini temel odağına almıştır. Lewin'e göre insanın tüm faaliyetleri yaşam sınırları içerisinde ortaya çıkmaktadır. İnsan yaşamının çerçevelendiği alan geçmişten bugüne, bugünden geleceğe tüm olayları ve davranışları etkilemektedir. Şu halde bireyin deneyim veya tecrübelerine göre yaşam çerçevesi değişir. Yaşam alanını sistematik ilişkiler ağı olarak tanımlayan kuram odaklanılması gerekenin parçalar değil bütünün kendisi olduğunu ortaya koymaktadır. Alan kuramını sosyoloji alanından yönetim alanına taşıdığımızda modern yönetim yaklaşımlarından sistem yaklaşımıyla örtüştürebiliriz. Nasıl insanın yaşam alanı içerisinde meydana gelen küçük değişiklikler tüm alanı değiştirebiliyorsa, örgüt bağlamında incelendiğinde de, üst ve alt sistemlerdeki değişim örgütün bütününe etki edebilmektedir. Bertalanffy'nin sistem yaklaşımı, kaos teoreminin 1şığındaki kelebek etkisi Kurt Lewin'in Alan Kuramı'nı yönetim bilimi açısından desteklemektedir (Tagay, 2010).

Tüm bu bilgilerden hareketle, bu çalışmada ülkemizde iş kazalarına oldukça sık rastlanan inşaat sektörü araştırma alanı olarak tercih edilmiştir. Bu bağlamda ilk olarak konunun teorik bir çerçevesi çizilmiştir. Çalışmanın ikinci bölümünde örgüt kültürü ve iklimi hususu ele alınmıştır. Bu maksatla örgüt kültürü, örgüt iklimi kavramları ele alınmış, örgüt iklimi kavramı dahilinde söz konusu iklimin türleri incelenmiş ve nihayetinde örgüt kültürü ile örgüt iklimi ilişkisi anlatılmıştır.

Üçüncü bölümde güvenlik iklimi ve iş sağlığı güvenliği hususu analiz edilmiştir. $\mathrm{Bu}$ kapsamda güvenlik iklimine yaklaşım çeşitliliği ele alınmıştır. Bu yaklaşımlar tutumsal yaklaşım, algısal yaklaşım ve karışık yaklaşımlar olarak üç kısımda irdelenmiştir. Bu 
bölümde ayrıca güvenlik iklimiyle ilgili araştırmalara yer verilmiş; iş sağlığı ve güvenliği hususunun gelişiminden ve ülkemizde inşaat sektöründe iş sağlığ ve güvenliği kapsamında gerçekleştirilen çalışmalara yer verilmiştir. Dördüncü ve son bölümünde ise inşaat sektöründe çalışan 79 katılımcının dahil edildiği anketin sonuçlarına yer verilmiştir. İlk olarak araştırma yönteminin açıklandığı uygulama kısmında toplam altı hipotez kurulmuş ve test edilmiştir. Güvenlik iklimi ve alt boyutlarına dair algının çalışanların demografik özelliklerine göre değişip değiş̧mediğinin test edildiği altı hipotezden dördü reddedilmiş, iki hipotez ise kabul edilmiştir.

\section{2. ÖRGÜT KÜLTÜRÜ VE İKLİMI}

\section{1. Örgüt Kültürü}

Örgüt, iş bölümü yapılarak, bir yaptırım gücü ve yükümlülük düzenine bağlı, önceden belirlenmiş olan ortak bir gayenin gerçekleştirilmesi amacıyla bir insan grubunun faaliyetlerinin koordinasyonudur (Öztürk 2010). Yönetim literatüründe ise örgüt, iki ya da daha çok insanın belli hedefleri gerçekleştirmek için bilinçli olarak bir araya geldikleri ve görev paylaşımı yaptıkları toplumsal varlıklar olarak tanımlanır. Örgüt kültürü; örgüt üyelerinin paylaştığı ve üyelerin davranışları ile tutumlarını yönlendiren, ancak genellikle bilinçsiz biçimde türetilmiş ve örgütün ana değerlerinden, normlarından, varsayımlarından ve inançlarından oluşan bir bütündür. Örgüt kültürü; fertlerine başka bir kimlik vermekte ve onların örgütsel bağlılığını sağlamakta ve üyelerin paylaştığı iç değişkenleri sunar. (Yüceler, 2009). Her örgütün kendine has yapısı, yönetimi, kahramanları, varoluş öyküsü ve özellikleri bulunur. $\mathrm{Bu}$ özelliklere göre katılımcılar örgüte bağlanır yahut uzaklaşır. İnsanların seçimini oluşturan bu karakteristik özellikler örgüt kültürünün de özünü oluşturur (Büyükkışlal1, 2015). Örgütü oluşturan bu değerler bütünü özetlenecek olursa (Koç, 2016):

Kültür, insanların paylaştığı değerlerle, inançlarla başlamaktadır; bu değerler bütünü örgütteki temel anlayış sistemini oluşturur. Kahraman, organizasyonlara daha önceden oldukça faydalı hizmetler sunmuş ve yaptıkları sebebiyle örgütünü başarıya taşımış kişidir. Bu anlamda örgütün kahraman, örgüt kültürüne yarar sağlayan, işgörenleri güdeleyici etkide, örgüt kültürünü örgüt dışında temsil eden bireylerdir. Törenler, örgütte özel bir olay için düzenlenen planlı aktivitelerdir ve simge olarak da kullanılır. Aynı zamanda örgütün diğer sembol ve simgeleri de bulunur ve bunlar, anlamı yeni gelenlere iletmek amacıyla kullanılan nesne yahut olay da olabilir. Öykü, masal ve efsaneler, örgüt kültürü bakımından önemli ve organizasyonun geçmişi ile alakalı olayların, abartılarak anlatılması neticesinde ortaya çıkmış olan kültür taşıyıcıları olarak ifade edilebilir. Dil, bir iletişim aracı olmakla beraber, kültürün yapı taşlarından biridir; her organizasyonun kendine has bir dili bulunmaktadır ve örgüt dilini yalnızca o örgüttün üyeleri kullanır. İsgörenler örgüt dilini kullanmakla, o kültürü benimsediklerini de gösterirler.

\section{2. Örgüt İklimi}

Örgüt iklimi, iş yaşamının sürdüğü ortama özgü şartların yansımasıdır. Bu anlamda örgüt iklimi; organizasyonların, kişisel ve fiziksel özellikleri ile o örgütteki üyelerin davranışlarını ve ilişkilerini oluşturan ortam şeklinde açıklanabilir. Örgütsel iklim, bir işyerinde yönetimin, kaidelerin ve aktarılan raporların anlattıklarından ziyade yöneticilerin davranışlarıyla onayladıkları faaliyetlerle alakalıdır (Başkaya, 2014). Örgüt iklimi; bir anlamda örgütün kişiliğini de oluşturur, örgütü diğer örgütlerden ayırdı̆̆ 1 gibi, örgütü betimler ve örgüte egemen olan, değişmez, sürekli niteliğine sahip, gözle görülüp elle tutulamayan, fakat örgüt üyeleri tarafından hissedilerek algılanan ve tüm bu özellikleri 
kapsayan psikolojik bir kavramdır (Yüceler, 2009). Örgüt ikliminin özelliklerini şöyle siralanmaktadır (Gül, 2015):

Kişilerin örgütün diğer üyeleriyle beraber, ortak kuralların ve uygulamaların yaratmış olduğu imgenin tamamıdır. Örgüt iklimi, bireyin değerlerini, inançlarını, tavır ve tutumlarını etkileyerek, iş yaşamındaki davranışlarını belirler ve yönetimin liderlik şeklini de etkiler. Örgütü dışarıdan biri ziyaret ettiğinde, o işyerindeki çalışanların aralarındaki ilişkileri gözleyerek, çalışanlarla konuştuğunda o örgütün iklimine dair bir kanıya varacaktır. (Başkaya 2014). Araştırmalarda örgüt ikliminin en az üç değişken yapıdan oluştuğu ifade edilmiştir:

Çevresel Değişkenler: Kişinin kendisi ile ilgisi olmayan, onu dışarıdan etkileyen ekonomik şartlar, sendikalaşma oranları, örgütün büyüklügü̈, yapısı ve benzeri değişkenlerdir. Kişisel Değişkenler: Örgüt üyelerinin yetenekleri, becerileri gibi kendi kişisel özellikleriyle alakalı yaklaşımlarını, değerlerini, inançlarını ve tutumlarını barındıran değişkenlerdir. Sonuç Değişkenler: Fiziksel ve bireysel değişkenlerin ortaklaşa kullanılması neticesinde ortaya çıkmaktadır. Çalışanın görevini yaparken istekliliği, memnuniyeti ve başarısı örneklendirilebilir.

1930'lu yıllardan bu yana araştırılmakta olan örgüt iklimi kavramı birçok bilimsel araştırmaya konu olmaya devam etmektedir. Kuramsal olarak inceleyecek olursak, örgüt iklimini odağına alan çalışmalar davranışı insan ve çevrenin bir fonksiyonu olarak gören K. Lewin'in "Alan Teorisi”ne ve sosyal psikoloji bakış açısına dayandırılmakta ve çevre değişkenlerini açıklamaya odaklanmaktadır (Aydoğan, 2004).

\subsection{1. Örgüt İklimi Türleri}

Örgüt iklimi, organizasyona kimlik kazandıran, çalışanların davranışlarını olumlu yahut olumsuz etkileyen önemli bir kavram olması yüzünden birçok araştırmanın da konusu olmuştur. Bu araştırmalar farklı örgüt iklimi türleri olduğunu göstermiştir. Aşağıda bu örgüt iklimi türleri anlatılmıştır:

\subsubsection{Açık İklim}

Açık örgüt ikliminde; işgörenler yöneticileriyle ve diğer çalışma arkadaşlarıyla dostça ilişkiler içinde çalışmakta ve bu yüzden örgütsel iklim olumlu algılanmaktadır. Dolayısıyla yönetici ve astların uyum içinde çalıştı̆̆ı ve örgüt üyelerinin morallerinin yüksek olduğu bir iklimdir.

\subsubsection{Bağımsız İklim}

Bağımsız örgüt ikliminde açık iklimin aksine yöneticilerle astları arasında bir psikolojik mesafe bulunur. Bu iklim, sosyal ihtiyaçlarla, sosyal tatmini daha öne çıkarır. Organizasyonda küçük baskı grupları bulunur, fakat bu gruplar ile çalışmak kişi açısından herhangi bir engel teşkil etmez, bu gruplarla uyumlu çalışabilirler. Kırtasiyecilik gerektiren işlemlerde engellenmezler (Koç, 2016).

\subsubsection{Kontrollü İklim}

Kontrollü iklim türünde, kontrol mekanizması yüksektir ve işgörenlerin birbirlerine anlayış gösterme seviyeleri düşüktür. İşgörenlerin birbirleri ile ilişkilerinden daha önemli olan görevlerini yerine getirmeleridir. İş tatmininin düşük olduğu gözlemlenmiştir. Kontrollü iklim türündeki örgütlerde üstlerin fikirleri önem içerir, çalışanların ne düşündüğü ise yöneticileri ilgilendirmez. (Akbaba, 2016). 


\subsubsection{Samimi İklim}

Samimi iklim tipinde, sosyal ihtiyaçların karşılanması daha önceliklidir. İdarecinin kendisi ile beraber diğer işgörenlerin aile olarak algılanması için çabaladığı bir iklim tipidir. Dolayısıyla sosyal ihtiyaçlar tatmini yüksek düzeyde gerçekleşir. Yaratılan aile havası sayesinde samimi iklim yaratılır ve çalışanlarda da aynı algı oluşturulur.

\subsubsection{Babacan İklim}

Babacan iklim türünde örgüt içinde samimiyet ve iş doyumu düşük seviyededir. Yöneticiler astlarla beraber çalışmaktan hoşnut değildir. Üstlerin, diğer işgörenlerin üzerindeki denetimi ve çalışanların sosyal gereksinimlerini giderme seviyeleri düşüktür. Bu iklim tipinde çalışanlarla birlik olmaya ve onları denetimi altında tutmaya çalışır, ne var ki bu durum başarısız bir üst-ast ilişkisine dönüşür. Personelin de iş doyumu bu iklim tipinde düşüktür.

\subsubsection{Kapalı İklim}

Kapalı iklimle babacan iklim tipleri birbirleriyle benzerlik gösterirler. Kapalı iklim tipinde de iş doyumu ve anlayış düzeyi düşük olduğu görülür. Personelin birbirleri ile samimiyet kurması ve sosyal ilişki yürütmeleri mümkün değildir. İdareciler emreder üslupla işgörenlerine yaklaştıkları için bu iklim herkese yansımaktadır. (Akbaba, 2016).

\subsubsection{Otoriter İklim}

Otoriter iklim türü; görev tanımına odaklanan, biçimsel otoriteden ödün verilmemesi yönünde hareket eden iklim türüdür. Güce dayalı olduğundan, bu iklim türünde başarısızlık ve korku, kaygı yüksektir. Organizasyon dışından gelen siyasal baskı fazladır, görevler ilgi çekici görünmez, işgörenlerin üstlerine bağımlıdır, örgütte çatışma yoğundur ve işe motivasyonun en az olduğu iklim tipidir (Koç, 2016).

\subsubsection{Demokratik İklim}

Demokratik iklim türünde, örgüt çalışanlarının iş ortamlarını kontrol edebilme imkânı bulunur. Kendi kendilerini yönetebilme ve karar alırken yöneticilerinin çalışanlara büyük bir esneklik alanı sağlamaktadır. İşgörenler beraber problem çözerler ve organizasyon amaçlarını gerçekleştirme hususunda gereken güdülenmeye sahiptirler (Özkul, 2013).

\subsubsection{Başarıya Yönelik İklim}

Bu iklim türünün oluşmasında günümüz şartları etkili olmuştur. Organizasyonların yoğun rekabet şartlarında devamlılığını sağlayabilmesi ve örgütsel kaynaklarını etkin kullanılmasına ihtiyaçları vardır. Dolayısıyla yenilikçi ve başarıya odaklı örgüt iklimleri oluşmuştur. (Özkul, 2013).

\section{3. Örgüt Kültürü ve Örgüt İklimi Farkları}

Daha önceki çalışmalarda örgüt iklimi, örgüt kültürüyle beraber incelenmiştir. Ancak yapılan araştırmalar ikisi arasında bazı farkları ortaya çıkartmıştır. Örgüt ikliminde personelin davranış ve tutumları sergilenirken, örgüt kültürü organizasyonun ortak davranış, düşünüş ve inanç özelliklerini yansıtır. Örgüt iklimi genellikle dış gözlemlere ve deneylere dayanırken, örgüt kültürü organizasyonun görünen etmenlerini ortaya çıkarır. Bununla beraber araştırmalar örgüt kültürü ile örgüt iklimi arasındaki ilişkiyi de göstermiştir. Söz konusu fakları aşağıdaki gibi sıralayabiliriz (Başkaya, 2014): 
Örgüt ikliminin psikolojinin temel ilkeleriyle alakalı bir kavram olduğu görüşü, örgüt ikliminin güdülenme, liderlik ve iş doyumu unsurlarını kapsadığı, iş doyumunun ve liderlik unsurlarının örgütsel davranışın en mühim boyutları olduğu ve dolayısıyla psikolojinin alanında incelenmesi gerektiği çıkarımıyla desteklenir. Örgüt kültürü değerleri ve varsayımları paylaştığından örgüt iklimini de kapsamaktadır.

Örgüt iklimi, personelin işletmede çalışma ortamına yönelik beklentilerini içerir ve bu çalışma ortamını algıladıkları genel bir havadır. Örgüt iklimini araştıranlar ölçeklerden yararlanır ve karşılaştırmalı olarak birçok örgüte uygulanabilir. Ama örgüt kültürü araştırmalarında kalitatif ölçekler seçilir ve işletmeler tek tek incelenir. Örgüt iklimi, insanların iş şartları ve çalışma ortamıyla ilgili beklentileri ve bu beklentilerin karşılanıp karşılanmadığına göre şekillenen algılarına dair havayı yansıtırken; örgüt kültürü bütün organizasyon fertlerinin davranışlarına biçim veren hâkim değerler, yargılar ve inançların bütününü ifade etmektedir (Gül 2015). Örgüt kültürü davranış kalıpları yaratırken, örgüt iklimi bu davranış kalıplarına ne düzeyde uyulduğuna dair bir gösterge sunar (Özkul 2013).

\section{GÜVENLİK İKLIMMI VE İŞ SAĞLIĞI VE GÜVENLİĞİ}

\subsection{Güvenlik İklimi Boyutları}

Güvenlik iklimi, belirli bir zamandaki güvenlik durumuna ilişkin algıları ifade eden psikolojik bir olgudur. Güvenlik iklimiyle ilgili literatürde, birçok tanım yer alır, ancak genel kabul görmüş bir tanım yoktur. Bu kavramı ilk kez kullanan Zohar'a göre güvenlik iklimi; örgüt ikliminin bir alt boyutu olarak işgörenlerin işyerlerindeki çalışma ortamlarına dair paylaştıkları esas algıların bir özetidir. Güvenlik iklimi ile ilgili çalışmalar çoğaldıkça tanımlar da artmıştır. Dedobbeleer ve Beland güvenlik iklimini iki ana unsurla açıklamaktadırlar: İlki; örgüt yöneticilerinin güvenlik konusuna gösterdikleri bağl1lık, ikincisi ise çalışanların güvenlik ile alakalı sürece ve işlemlere katılımıdır (Türen vd., 2014). Güvenlik iklimi, işgörenlerin güvenlik politikalarına ve uygulamalarına dair paylaştıkları algılarıdır (Özaslan vd., 2011). Griffin ve Neal ise araştırmalarında güvenlik ikliminin iki temel boyutu olduğunu anlatmışlar ve bu algılardan ilkinin işletmenin güvenliğe dair politikaları, prosedürleri ve ödülleri algılanma biçimidir, diğeri ise bunların da ötesinde işgörenlerin işletmenin güvenliğe ne düzeyde değer verildiğine yönelik algılarıdır (Türen vd., 2014). Flin ve arkadaşları, üzerinde henüz fikir birliğine varılamamış ve bir tartışma konusu olan güvenlik ikliminin boyutları ile ilgili genel kabul görecek bir içerik oluşturma amacıyla değişik ülkelerde 18 çalışma yapmışlardır. Sonuçlara göre çoğunlukla rastlanmış boyutlar aşağıdaki gibidir.

\subsubsection{Tutumsal Yaklaşım}

Tutumsal yaklaşımda güvenliğe dair tutumların ölçümüne odaklanılmaktadır. İşgörenlerin tutumları organizasyonun içindeki ve dışındaki inançların tesirinde kalabilir. $\mathrm{Bu}$ bağlamda örgütlerin önceliği; çalışanın sağlığı, iş güvenliği ve çalışanın güvenliği olması gerekmektedir. Bunun için işgörenlere güvenli bir iş ortamı sağlayabilmek için gerekli önlemler alınmalı ve özendirici davranışlar sergilenmelidir (Uslu 2014).

\subsubsection{Algısal Yaklaşım}

$\mathrm{Bu}$ yaklaşım, işgörenin, uygulanan işletme politikalarını ve uygulamalarını kapsayan iş ortamı ile ilgili algıları ile güvenlik uygulamasının sonuçları arasındaki ilişkilerdir. İşletme politikaları ve uygulamalar çalışanlarda çalışma ortamının güvenliğine dair bir algı oluşturmaktadır. 


\subsubsection{Karışık Yaklaşımlar}

$\mathrm{Bu}$ tür yaklaşımlara yönelik gerçekleştirilen araştırmalarda bireysel alg1 ve tutumların karışımı yapılmakta ve iş ile alakalı gösterilen tutumlarla, davranışlarda sahip olunan inançlar, eğilimler bu yapıya dahil edilmektedir. Bu model ile gerçekleştirilen çalışmalarda; iş yükünün çokluğu, kişinin risk algısı, görevi yaparken gösterilen hız türündeki değişkenler güvenlik ikliminin bir boyutu olarak değerlendirilir (Koç 2016).

\subsection{Güvenlik İklimi Araştırmaları}

Güvenlik iklimi ile ilgili çalışmalara öncülük eden Zohar, dört yüz işçiyle yirmi farklı alanda gerçekleştirdiği araştırmalarda konuyu sekiz boyutta incelemiştir. Bu boyutlar daha sonraki başka çalışmalarda değişikliğe uğramıştır. Zohar'ın belirlediği sekiz güvenlik iklimi boyutu, güvenlik programlarının algılanan önemi, yönetimin güvenliğe karş1 algılanan tutumu, güvenlik davranışının terfilere etki algısı, işyerinde algılanan risk düzeyi, güvenlik için gereken iş temposunun algılanan etkisi, güvenlik personelinin algılanan statüsü, sosyal konum üzerinde güvenlik davranışının algılanan etkisi ve güvenlik biriminin algilanan statüsüdür (Sözer 2012). DeJoya ve diğerleri 2004 y1lında gerçekleştirdikleri araştırmalarda; güvenlik ikliminin belirleyici olan unsurlara odaklanmışlardır. Araştırmada demografik değişkenler kontrol edilmiş ve üç unsurun güvenlik iklimini etkileme biçimi incelenmiştir. Bulgulara göre; örgüt ikliminin güvenlik iklimine etkisinin yüksek olduğu anlaşılmaktadır. Aynı zamanda yüksek güvenlik performansının belirleyicisi olarak; güvenli iş şartları, özel güvenlik politikaları ve tehlike kontrolü biçiminde tespit edilmiştir (Özaslan vd., 2011).

Neal, Griffin ve Hart Avustralya'daki bir hastanede 525 kişiye, kendi geliştirdikleri güvenlik performansı modeli yardımıyla araştırmayı uygulamış, örgüt iklimi ve güvenlik ikliminin kişisel güvenlik davranışlarına etkisini incelemişlerdir. Güvenlik iklimi; yönetim değerleri, iletişim, eğitim ve güvenlik sistemi boyutlarıyla değerlendirilmiş ve analizler sonucunda güvenlik ikliminin, güvenli davranışı doğrudan etkilediği görülmüştür (Külekçi 2012). Gyekye 2006'da bir çalışma yaparak, kıdemli işgörenlerin, az kıdemli çalışanlara oranla yüksek güvenlik iklimi algısının olduğunu ortaya koymuştur. Araştırma sonuçlarına bakıldığında; güvenlik ikliminin daha çok işgörenlerin risk algıları ile iş doyumlarının, gerçekleşen iş kazaları ve meslek hastalıklarıyla olan ilişkisi ele alınmaktadır (Ö̈zaslan vd., 2011).

\section{3. İş Sağlı̆̆ı ve Güvenliği}

İnsan çevresiyle bir bütündür. Dolayısıyla diğer insanlarla etkileşim halinde olduğu ortamlardan etkilenmektedir. Bu doğrultuda iş sağlığı ve güvenliği kavramları, iş hayatının insanlara yarattığı etkilerden hareketle incelenmiştir. İş sağlığı ve güvenliği insanları fiziksel, ruhsal ve sosyal olarak etkilediği çalışmalardan da anlaşılmaktadır. (Ersan 2014). İs sağlığı ve güvenliği konusu güvenlik ikliminin önemli bir bölümünü oluşturmaktadır. Örgütler açısından en önemli kaynak insan kaynağı olduğundan, çalışanların maruz kaldıkları iş kazalarıyla meslek hastalıkları, iş sağlığı ve güvenliği ile ilgili farklı uygulama ve stratejilerin geliştirilmesini sağlamıştır. Sosyal devlet kavramı çağdaş bir devlet ve toplum anlayışını da beraberinde getirmektedir. Sosyal devlet, vatandaşları ile ilgilendiği gibi, daha fazla alanda uygulama yapar. Sosyal devlet toplumu ise daha çok hakkının bilincinde olan ve haklarını kullanma yetisi gösteren insanlardan oluşur. (Ersan 2014).

İş sağlığı kavramı; işgörenlerin iş şartlarıyla kullanılmakta olan araç ve gereçlerden doğacak tehlikelerden arınmış yahut bu tehlikelerin en alt seviyeye indirilmiş olduğu bir iş ortamını ve burada huzurlu şekilde çalışmayı anlatmaktadır (Ersan 2014). İş sağlığı; 
işgörenlerin, bedensel, ruhsal ve sosyal olarak korunması, kollanarak bu doğrultuda bilinç geliştirilmesidir. İş şartlarından dolayı işgörenlerin sağlığını yitirmesini önlemek yahut işlerini yaparken sağlıklarını kötü etkileyecek unsurlardan korumaktır. (Özaslan 2011). İşgörenler vakitlerinin büyük kısmını çalıştıkları yerlerde harcadıkları için, verimli ve mutlu olmaları maksadıyla çalışma ortamındaki olumlu havanın katkısı önemlidir. (Koç 2016). İş sağlığı ve iş güvenliği kavramları ayrı ayrı tanımlanabilen kavramlar olsa da daha önce de değinildiği gibi pek çok kaynakta bu iki kavramın birlikte ele alındığ görülmektedir. Geniş bir ifadeyle, yalnızca işletmeden değil, işletmenin dışından da doğacak ve işçilerin sağliklarıyla güvenliklerini olumsuz etkileyecek risklere karşı tedbir almaktır (Özaslan 2011). Günümüzde Uluslararası Çalışma Örgütü (ILO) ve Dünya Sağllk Örgütü’ne (WHO) göre işçi sağlığı ve iş güvenliği ortak komisyonunda iş sağlığ 1 ve güvenliği üç noktada özetlenmiştir:

İşgören sağlığının ve çalışma potansiyelinin korunması ve iyileştirilmesi. İş ortamıyla iş uygulamalarının, işgörenlerin güvenlikleri ve sağlıkları doğrultusunda iyileştirilmesi. İş organizasyonunun ve çalışma kültürünün işletmedeki sağlığı ve güvenliği destekleyecek biçimde geliştirilerek, bu uygulamaların pozitif bir iş ortamı ve faaliyetlerin sorunsuz gerçekleşmesi ve böylece verimliliğin arttırılması.

\subsection{1. İş Sağlığı ve Güvenliğinin Gelişimi}

İşören sağlığı ve güvenliği konusu kadim zamanlardan günümüze değin farklı safhalardan geçip, çağımızdaki bilimsel ve sosyal anlamını kazanmıştır. İnsanların ilk çağlarda kullandıkları iş aletleri yerini makinelere bırakınca üretim süreci karmaşıklaşmıştır. İnsanlık tarihinde iş ortamı, üretim araçları ve çalışan insan devamlı etkileşimdedir. $\mathrm{Bu}$ da farklı sağlık ve güvenlik problemlerini beraberinde getirmiştir. (Tekin 2013). İsçi sağlı̆̆ ve iş güvenliği hakkındaki yazılı çalışmaların ilk örnekleri olarak, Hipokrat'ın (M.Ö.460-370) kurşun zehirlenmelerinin başlıca belirtileri üzerine gerçekleştirdiği çalışma ve Aristo'nun (M.Ö. 384-222) koşucuların hastalıklarını ve gladyatörler için özel diyet tariflerini içeren çalışmaları gösterilmektedir (Uslu 2014). 1493 'le 1541 yılları arasında maden işçilerindeki meslek hastalıklarını inceleyerek, ilk iş hekimliği kitabı olarak kabul edilen De Morbis Metallicis, Alman düşünür ve hekim Paraselsus tarafindan yazılmıştır. İşgören sağlığı ve güvenliği ile ilgili yasal düzenleme ilk defa 19. asırdan sonra yapılmıştır. Sanayi devrimiyle beraber, makineleşme başlamış, bu da şehirleşmeyi, basının gelişmesini ve sosyal konuların önemsemesini doğurmuştur. Konuya dair ilk yasal düzenleme İngiltere'de yapılmıştır. Baca temizleyicilerin yaşadıkları önemli sağlı problemleri yüzünden 1788'de Baca Temizleyicileri Yasası çıkarılmıştır. (Külekçi 2012).

Dünyada meslek hastalıklarıyla iş kazalarının engellenmesi için yapılan çalışmalarda sendikaların etkisi olmakla beraber, 1919 yılında faaliyete başlayan Uluslararası Çalışma Örgütü Milletler Cemiyeti'ne bağlı olarak mühim çalışmalarda bulunmuştur. 1946 yılında Birleşmiş Milletler'le imzaladığı anlaşma sonucunda bu konuda bir uzmanlık kuruluşu olmuştur. Uluslararası Çalışma Örgütü'nün en önemli faaliyet alanlarından biri iş hayatı ve sosyal şartlarla alakalı uluslararası standartları oluşturmaktır. Memleketimizde çalışma haklarının korunması ile ilgili ilk önlem Cumhuriyet'in kuruluşundan önce 1921 tarihine rastlar. Bu yıllarda, Milli Mücadele sırasında kullanılan tek enerji kaynağı kömür olduğundan, kömür üretiminin kesintisiz sürdürülebilmesi büyük önem kazanmıştır. Bu devamlılığın sağlanması için büyük bir işçi kitlesinin ağır çalışma şartları içinde bulunduğu Zonguldak ve Ereğli Kömür İsletmeleri'nde konunun üzerinde önemle durulmuş ve peş peşe iki yasa çıkarılmıştır. 114 ve 151 sayılı yasalar kömür işçilerinin çalışma şartlarının düzeltilmesine yönelik hükümler getirmektedir" (Tekin 
2013). 1946'da Çalışma ve Sosyal Güvenlik Bakanlığı kurulmuştur. Böylece işgörenlerin sağlıkları iş güvenlikleri bakanlık seviyesinde incelenmeye başlamıştır. 1949'da WHO'ya üye olunarak çalışan sağlığ 1 daha fazla önemsenmeye başlanmıştır. 6331 sayılı İş Sağlığı ve Güvenliği Kanunu 30 Haziran 2012'de Resmî Gazete'de yayımlanmıştır. Böylece işgörenlerin sağlı̆̆ , işletmelerin güvenliği ile ilgili kapsamlı bir yasal düzenleme yapilmıştır (Uslu 2014).

\subsubsection{Türkiye İnşaat Sektöründe İş Sağlığı ve Güvenliği: Yapılan Çalışmalar ve Mevcut Durumun Değerlendirmesi}

Türkiye'de iş sağlı̆̆1 ve güvenliğini inşaat sektöründe değerlendiren birçok çalışma yapılmıştır. Bu çalışmalar aşağıda özetlenerek aktarılmıştır: Baradan'ın (2006) inşaat sektörü ile ilgili çalışmasında işçi sağlığı ve güvenliğinin Türkiye'deki mevcut durumuyla gelişmiş ülkelerdeki durum karşılaştırılmıştır. Akkaş (2006) toplu konut sektörü ile ilgili bir çalışma yaparak Türkiye'deki yapı üretiminde işçi sağlığı ve iş güvenliği konusunu araştırmıştır. Demircan'ın (2008) yaptığı araştırmada inşaat sektöründeki işçi sağlığıyla güvenliğinin ekonomik ve toplumsal unsurları incelenmiştir. Karadağ (2010) çalışmasında Türk inşaat sektörünün iş güvenliği açısından risk analizini incelemiştir. 2002 ve 2007 yılları arasındaki iş kazaları istatistiklerinin incelendiği araştırmada kazaların sıklığ dikkate alınarak risk analizi ve inşaat sektörü ile diğer sektörler karşılaştırılmıştır.

Obuz'un (2016) yaptığı çalışmada inşaat sektöründe çalışanların iş sağlığı ve güvenliği hakkındaki bilgi düzeyleri konu edilmiştir. Karaosmanoğlu'nun (2016) yaptığ araştırmada inşaat projelerinin iş sağlığıyla güvenliği konusunda iyileştirmelerin sözleşme ve benzeri düzenlemelerle arttırılması incelenmiştir. Kızgın (2017) yaptığı çalışmada inşaat işçilerinin yüksekte çalışmaları ve kullanılan iskelelerin iş sağlığı ve güvenliği risklerine etkisini incelemiştir. Temel (2017) yaptığı çalışmada inşaat işçilerinin iş sağlığ ve güvenliği konusunda uygulama ve algılama düzeyini araştırma konusu edinmiştir. Türkiye'deki iş kazalarıyla ilgili olarak Sosyal Güvenlik Kurumu'nun verilerine göre, 2014 yılında 221 bin 366 iş kazası meydana gelmiş, bu kazaların 1.626'sı ölümle, 1.421'i ise sürekli iş göremezlikle sonuçlanmıştır. (Koç 2016).

\section{4. ÇALIŞANLARIN GÜVENLİK İKLİMİ İLE İLGILİ ALGILARI ÜZERINE İNŞAAT SEKTÖRÜNDE BİR UYGULAMA}

\subsection{Araştırmanın Yöntemi}

Çalışmanın bu bölümünde araştırma modeline, evren ve örneklemine, ölçme araçlarına, güvenilirliğe, verilerin toplanmasına ve analizine yönelik bilgilere yer verilmiştir.

\subsubsection{Evren ve Örneklem}

Araştırma inşaat sektöründe ve İstanbul ilinde gerçekleştirildiğinden evreni; İstanbul ilinde bulanan inşaat sektörü olarak tanımlanmıştır. Araştırmanın örneklemini ise İstanbul ilinde İnşaat sektöründe çalışan ve rastgele örnekleme ile seçilmiş 79 kişi oluşturmaktadır.

\subsubsection{Veri Toplama Araçları ve Teknikleri}

Araştırmada veri toplama aracı olarak kullanılan anket formu üç bölümden oluşmaktadır. Formun ilk bölümünde katılımcıların demografik özellikleriyle ilgili sorular yer almaktadır. Demografik analiz sorularının sayısı altı adettir. Formun ikinci kısmında Zohar ve Lurio'nun (2005) örgütsel güvenlik iklimi ölçeği baz alınarak Fugas ve diğerleri 
tarafından geliştirilmiş olan güvenlik iklimi ölçeği kullanılmıştır. Toplam 21 maddeden oluşan söz konusu ölçek, Avcı (2014) tarafından dilimize tercüme edilmiş, geçerlilik ve güvenilirlik analizleri yapılmıştır. Avcı'nın gerçekleştirdiği güvenilirlik analizi sonucu güvenilirlik iklimi ölçeğinin Cronbach Alpha değeri 0,85 olarak tespit edilmiştir (Koç 2016). Söz konusu ölçeğin bu çalışmada belirlenen güvenirlik değeri 0,91 olarak tespit edilmiştir. Araştırmada Güvenliğe Yönelik Tutum kavramı işgörenlerin iş sağlığı ve güvenliğine dair olumlu veya olumsuz değerlendirmeleri anlamına gelmektedir. 21 sorudan meydana gelen forma ilave olarak $\dot{I}_{S ̧}$ Sağlı̆̆ ve Davranışlarına Yönelik Algllanan Kontrol ve Güvenliğe Uyum Davranışı ile alakalı sorular da dahil edilmiştir (Koç 2016). Araştırmada kullanılan tüm ölçeklere ait güvenilirlik değerlerinin 0,60 ila 1,00 arasında olduğu görülmektedir. Buna göre ölçeklerin tamamı Güvenilir veya Yüksek Derecede Güvenilir olarak değerlendirilebilecektir.

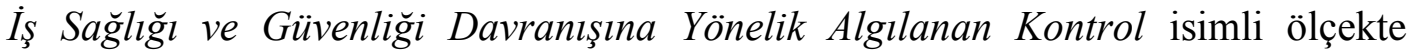
yeralan 22 numaraları ifade güvenilirlik değerini düşürdüğünden $(0,590)$ anket formundan çıkarılmıştır. Söz konusu ölçeğe diğer iki ifade ile güvenilirlik testi uygulandığında bulunan değer 0,612 olmuştur. Yeni değerin ölçeği Az Güvenilir kategorisinden çıkararak Güvenilir kategorisine yükseltmesinden ötürü, ölçeğin bu hali ile kullanılmasına karar verilmiştir.

Tablo 1. Güvenlik İklimi Ölçeği ile Alt Boyutlarının Güvenirlik Değerleri

\begin{tabular}{|l|l|}
\hline & $\alpha$ \\
\hline Örgütsel Güvenlik İklimi & 0,802 \\
\hline Şeflerin Tanımlayıcı Normları & 0,911 \\
\hline $\begin{array}{l}\text { Şeflerin Önleyici Normları } \\
\begin{array}{l}\text { Çalışma Arkadaşlarının } \\
\text { Tanımlayıcı Normları }\end{array}\end{array}$ & 0,876 \\
\hline $\begin{array}{l}\text { Çalışma Arkadaşlarının Önleyici } \\
\text { Normları }\end{array}$ & 0,735 \\
\hline $\begin{array}{l}\text { İş Sağlığı ve Güvenliğine Yönelik } \\
\text { Tutum }\end{array}$ & 0,904 \\
\hline $\begin{array}{l}\text { İş Sağlı̆̆ı ve Güvenliği Davranışına } \\
\text { Yönelik Algılanan Kontrol }\end{array}$ & 0,612 \\
\hline Güvenliğe Uyum Davranışı & 0,890 \\
\hline Önleyici Güvenlik Davranışı & 0,874 \\
\hline
\end{tabular}

\subsubsection{Araştırmanın Modeli ve Hipotezleri}

$\mathrm{Bu}$ araştırmada inşaat sektöründe yeralan çalışanların güvenlik iklimi algılarının düzeyleriyle söz konusu algılarının cinsiyet, eğitim düzeyi ve çalışma şekillerine (vardiyalı sistem vb.) göre farklarının tespit edilerek yorumlanması amaçlanmaktadır. Bu araştırmanın bağımsız değişkenleri; medeni durum, cinsiyet, eğitim düzeyi, çalışılan sektör 
ve çalışma şekli, bağımlı değişkeni ise; güvenlik iklimi algısı olarak ifade edilebilecektir. Araştırmanın hipotezleri şu şekilde oluşturulmuştur:

H1: Güvenlik iklimi algısı cinsiyete göre istatistiksel açıdan anlamlı düzeyde farklılık gösterir.

H2: Güvenlik iklimi algısı eğitim düzeyine göre istatistiksel açıdan anlamlı düzeyde farklılık gösterir.

H3: Güvenlik iklimi algısı medeni duruma göre istatistiksel açıdan anlamlı düzeyde farklılık gösterir.

H4: Güvenlik iklimi algısı sektöre göre istatistiksel açıdan anlamlı düzeyde farklılık gösterir.

H5: Güvenlik iklimi algısı çalışma şekline göre istatistiksel açıdan anlamlı düzeyde farklılık gösterir.

\subsection{Bulgular}

$\mathrm{Bu}$ bölümde, çalışmanın amaçları doğrultusunda inşaat sektöründe çalışan kişilere uygulanan anket formunda sağlanan verilerin analiz edilmesiyle elde edilen bulgulara ve yorumlara yer verilmiştir. İlk olarak araştırmaya dahil olan inşaat sektöründe çalışanların demografik özellikleriyle ilgili analizlere yer verilmiş ve ardından hipotezlerin test edilmesiyle elde edilen bulgular paylaşılmıştır.

\subsubsection{Demografik Bulgular}

Araştırmaya dahil olan katılımcıların demografik özelliklerine göre dağılımları Tablo 2'de gösterilmiştir.

Tablo 2. Katılımcıların Demografik Bilgileri

\begin{tabular}{|l|l|l|l|}
\hline Değişkenler & Kategoriler & $\mathbf{n}$ & \% \\
\hline \multirow{3}{*}{ Cinsiyet } & Kadın & 30 & 38 \\
\cline { 2 - 4 } & Erkek & 49 & 62 \\
\hline \multirow{4}{*}{ Eeğitim Düzeyi } & Bekar & 41 & 51,9 \\
\hline & Evli & 38 & 48,1 \\
\cline { 2 - 4 } & Ö̈n Lisans/ Lisans & 49 & 3,8 \\
\cline { 2 - 4 } & Yüksek Lisans & 21 & 7,6 \\
\hline \multirow{3}{*}{ Sektör } & Kamu & 62 & 26,6 \\
\hline Çalışma Şekli & Gündüz & 72 & 78,5 \\
\cline { 2 - 4 } & Özel & 17 & 21,5 \\
\hline
\end{tabular}




\begin{tabular}{|l|l|l|}
\cline { 2 - 4 } Vardiyal 1 & 5 & 6,3 \\
\hline Gece & 2 & 2,5 \\
\hline
\end{tabular}

Buna göre; katılımcıların büyük çoğunluğu erkeklerden (\%62) meydana gelmektedir. Katılımcıların \%51,9'unun evli olduğu görülmektedir. Katılımcıların oldukça büyük bir çoğunluğunun ise üniversite $(\% 62)$ veya yüksek lisans $(26,6)$ mezunu olduğu belirlenmiştir. Araştırmaya dahil olan katılımcıların \%62'si kamu sektöründe görev almaktadır. Buna karşın \%17 oranında katılımcı özel sektörde görev aldığını belirtmiştir. Katılımcıların ekserisi (\%72) yalnızca gündüz, belirlenmiş mesai saatlerinde çalışmaktadır. $\% 6,3$ oranında katılımcı vardiyalı bir çalışma sistemine sahipken, $\% 2,5$ oranında katılımcı ise gece mesaisinde görev almaktadır.

\subsubsection{Güvenlik İklimi Algısına Dair Bulgular}

Tablo 3'de katılımcıların örgütsel güvenlik iklimi algılarının düşük olmadığı, orta bir seviyede olduğu $(3,82)$ görülmektedir.

Tablo 3. Araştırma Katılımcılarının Güvenlik İklimi Algı Düzeyleri

\begin{tabular}{|l|l|l|l|}
\hline & N & Ortalama & $\begin{array}{l}\text { Std. } \\
\text { Sapma }\end{array}$ \\
\hline Örgütsel Güvenlik İklimi & 79 & 3,82 & 0,689 \\
\hline Şeflerin Tanımlayıcı Normları & 78 & 3,27 & 0,960 \\
\hline Şeflerin Önleyici Normları & 79 & 3,71 & 0,890 \\
\hline Çalışma Arkadaşlarının Tanımlayıcı Normları & 79 & 3,35 & 0,772 \\
\hline Çalışma Arkadaşlarının Önleyici Normları & 79 & 3,39 & 0,829 \\
\hline İș Sağlığı ve Güvenliğine Yönelik Tutum & 79 & 4,38 & 0,688 \\
\hline $\begin{array}{l}\text { İș Sağlığı ve Güvenliği Davranışına Yönelik } \\
\text { Algılanan Kontrol }\end{array}$ & 78 & 3,66 & 0,799 \\
\hline Güvenliğe Uyum Davranışı & 78 & 3,59 & 1,055 \\
\hline Önleyici Güvenlik Davranışı & 78 & 3,46 & 0,996 \\
\hline
\end{tabular}

Buna ilave olarak örgüt iklimi alt boyutlarından olan $\dot{I}_{s ̧}$ Să̆lı̆̆ ve Güvenliğine Yönelik Tutum boyutunun en yüksek seviyede olduğu $(4,38)$ olduğu görülmektedir. Bu neticeden yola çıkarak, araştırmaya dahil olan katılımcıların iş sağlığı ve güvenliğine yönelik tutumlarının yüksek olduğu söylenebilir.

\subsubsection{Güvenlik İklimi Algılarını Demografik Özelliklere Göre Farkları}

Tablo 4'de katılımcıların cinsiyetlerine göre güvenlik iklimi algılarının değişip değişmediğine yönelik gerçekleştirilen T-testi sonuçlarına yer verilmiştir.

Tablo 4. Katılımcıların Güvenlik İklimi Algılarının Cinsiyete Göre Farkları 


\begin{tabular}{|c|c|c|c|c|c|c|}
\cline { 3 - 6 } \multicolumn{2}{c|}{} & $\mathbf{N}$ & Ortalama & $\begin{array}{c}\text { Std. } \\
\text { Sapma }\end{array}$ & t & p \\
\hline $\begin{array}{c}\text { Örgüitsel } \\
\text { Güvenlik } \\
\text { İklimi }\end{array}$ & Kadın & 30 & 3,988 & 0,614 & \multirow{2}{*}{1,696} & 0,094 \\
\cline { 2 - 5 } & Erkek & 49 & 3,721 & 0,718 & \\
\hline
\end{tabular}

Kadın ve erkeklerin güvenlik iklimi algılarına yönelik ortalamaları birbirine yakın olarak tespit edilmiştir. Buna göre $(p>0,05)$ olduğundan katılımcıların cinsiyetlerine göre güvenlik iklimi algılarının değişim göstermediği söylenebilir. $\mathrm{Bu}$ sonuç H1'in reddedildiğini göstermektedir. Tablo 5'de katılımcıların cinsiyetlerine göre örgütsel güvenlik iklimi alt boyutlarını algılayışların değişim gösterip göstermediğine yönelik gerçekleştirilen T-testi sonuçlarına yer verilmiştir. Buna durum örgütsel güvenlik alt boyutlarının hiçbirinin katılımcıların cinsiyetine göre alg1 farklılığı içermediğini göstermiştir.

Tablo 5. Katılımcıların Örgütsel Güvenlik İklimi Alt Boyutları İle İlgili Algılarının Cinsiyete Göre Farkları

\begin{tabular}{|c|c|c|c|c|c|c|}
\hline & & $\mathbf{N}$ & Ortalama & Std. Sapma & $\mathbf{t}$ & $\mathbf{p}$ \\
\hline \multirow{2}{*}{$\begin{array}{c}\text { Şeflerin Tanımlayıcı } \\
\text { Normları }\end{array}$} & Kadın & 29 & 3,459 & 0,94 & \multirow{2}{*}{1,293} & \multirow{2}{*}{0,200} \\
\hline & Erkek & 49 & 3,17 & 0,964 & & \\
\hline \multirow{2}{*}{$\begin{array}{c}\text { Şeflerin Önleyici } \\
\text { Normları }\end{array}$} & Kadın & 30 & 3,822 & 0,704 & \multirow{2}{*}{0,818} & \multirow{2}{*}{0,416} \\
\hline & Erkek & 49 & 3,653 & 0,988 & & \\
\hline \multirow{2}{*}{$\begin{array}{c}\text { Çalışma } \\
\text { Arkadaşlarının } \\
\text { Tanımlayıcı Normları }\end{array}$} & Kadın & 30 & 3,433 & 0,722 & \multirow{2}{*}{0,708} & \multirow{2}{*}{0,481} \\
\hline & Erkek & 49 & 3,306 & 0,804 & & \\
\hline \multirow{2}{*}{$\begin{array}{c}\text { Çalışma } \\
\text { Arkadaşlarının } \\
\text { Önleyici Normları }\end{array}$} & Kadın & 30 & 3,522 & 0,761 & \multirow{2}{*}{1,089} & \multirow{2}{*}{0,279} \\
\hline & Erkek & 49 & 3,312 & 0,867 & & \\
\hline \multirow{2}{*}{$\begin{array}{c}\text { İş Sağlığı ve } \\
\text { Güvenliğine Yönelik } \\
\text { Tutum }\end{array}$} & Kadın & 30 & 4,666 & 0,557 & \multirow[b]{2}{*}{0,791} & \multirow[b]{2}{*}{0,432} \\
\hline & Erkek & 49 & 4,34 & 0,758 & & \\
\hline \multirow{3}{*}{$\begin{array}{c}\text { İş Sağlığı ve Güvenliği } \\
\text { Davranışına Yönelik } \\
\text { Algılanan Kontrol }\end{array}$} & Kadın & 29 & 3,517 & 0,85 & \multirow[b]{2}{*}{$-1,219$} & \multirow[b]{2}{*}{0,227} \\
\hline & Erkek & 49 & 3,744 & 0,764 & & \\
\hline & Kadın & 30 & 3,388 & 1,002 & $-1,393$ & 0,168 \\
\hline $\begin{array}{c}\text { Güvenliğe Uyum } \\
\text { Davranışı }\end{array}$ & Erkek & 48 & 3,729 & 1,077 & & \\
\hline
\end{tabular}




\begin{tabular}{|c|c|c|c|c|c|c|}
\hline $\begin{array}{c}\text { Önleyici Güvenlik } \\
\text { Davranışı }\end{array}$ & Kadın & 40 & 3,4 & 0,894 & \multirow{2}{*}{0,429} & \multirow{2}{*}{0,669} \\
\cline { 2 - 5 } & Erkek & 48 & 3,5 & 1,063 & & \\
\hline
\end{tabular}

Tablo 6'da katılımcıların eğitim düzeylerine göre örgütsel güvenlik iklimi algılarının değişip değişmediğini gösteren Anova testi sonuçlarına yer verilmiştir. ANOVA testinden önce varyansların homojenlik testi yapılmıştır ve Levene testi $p$ değeri sonucu analizlere devam edilmiştir. Buna göre eğitim düzeylerine göre çalışanların örgütsel güvenlik iklimi algı ortalamaları farklı görünse dahi ( $p>0,5)$ olduğundan $\mathrm{H} 2$ reddedilmiştir.

Tablo 6. Katılımcıların Güvenlik İklimi Algılarının Eğitim Düzeylerine Göre Farkları

\begin{tabular}{|c|c|c|c|c|c|}
\hline & & $\mathbf{N}$ & Ortalama & Std. Sapma & $\mathbf{p}$ \\
\hline \multirow{4}{*}{$\begin{array}{c}\text { Örgütsel } \\
\text { Güvenlik } \\
\text { İklimi }\end{array}$} & Lise & 3 & 4,555 & 0,384 & \multirow{4}{*}{0,055} \\
\hline & Yüksek Okul & 6 & 3,722 & 0,31 & \\
\hline & Ön Lisans/ Lisans & 49 & 3,693 & 0,688 & \\
\hline & Yüksek Lisans & 21 & 4,047 & 0,707 & \\
\hline
\end{tabular}

Tablo 7'de katılımcıların eğitim düzeylerine göre örgütsel güvenlik iklimi alt boyutlarına dair algılarının değişim gösterip göstermediğine dair gerçekleştirilen Anova testinin sonuçlarına yer verilmiştir.

Tablo 7. Katılımcıların Örgütsel Güvenlik İklimi Alt Boyutları ile İlgili Algılarının Eğitim Düzeylerine Göre Farkları

\begin{tabular}{|c|c|c|c|c|c|}
\hline & & & & \\
\hline & & $\mathbf{N}$ & $\begin{array}{c}\text { Ortalam } \\
\text { a }\end{array}$ & Std. Sapma & $\mathbf{p}$ \\
\hline \multirow{4}{*}{$\begin{array}{c}\text { Şeflerin } \\
\text { Tanımlayıcı } \\
\text { Normları }\end{array}$} & Lise & 3 & 3,889 & 0,192 & \multirow{4}{*}{$\mathbf{0 , 0 2}$} \\
\hline & \begin{tabular}{|l|} 
Yüksek Okul \\
\end{tabular} & 6 & 3,667 & 0,516 & \\
\hline & Ön Lisans/ Lisans & 48 & 3,014 & 0,963 & \\
\hline & Yüksek Lisans & 21 & 3,683 & 0,928 & \\
\hline \multirow{4}{*}{$\begin{array}{c}\text { Şeflerin Önleyici } \\
\text { Normları }\end{array}$} & Lise & 3 & 4,444 & 0,385 & \multirow{4}{*}{0,231} \\
\hline & Yüksek Okul & 6 & 3,778 & 0,272 & \\
\hline & Ön Lisans/ Lisans & 49 & 3,578 & 1,002 & \\
\hline & Yüksek Lisans & 21 & 3,921 & 0,690 & \\
\hline \multirow{2}{*}{$\begin{array}{c}\text { Çalışma } \\
\text { Arkadaşlarının }\end{array}$} & Lise & 3 & 4,333 & 0,333 & \multirow{2}{*}{$\mathbf{0 , 0 0 5}$} \\
\hline & Yüksek Okul & 6 & 3,722 & 0,328 & \\
\hline
\end{tabular}




\begin{tabular}{|c|c|c|c|c|c|}
\hline \multirow{2}{*}{$\begin{array}{c}\text { Tanımlayıcı } \\
\text { Normları }\end{array}$} & Ön Lisans/ Lisans & 49 & 3,143 & 0,779 & \\
\hline & Yüksek Lisans & 21 & 3,603 & 0,688 & \\
\hline \multirow{4}{*}{$\begin{array}{c}\text { Çalışma } \\
\text { Arkadaşlarının } \\
\text { Önleyici } \\
\text { Normları }\end{array}$} & Lise & 3 & 3,889 & 0,509 & \multirow{4}{*}{0,006} \\
\hline & Yüksek Okul & 6 & 3,722 & 0,534 & \\
\hline & Ön Lisans/ Lisans & 49 & 3,143 & 0,908 & \\
\hline & Yüksek Lisans & 21 & 3,810 & 0,454 & \\
\hline \multirow{4}{*}{$\begin{array}{c}\text { İş Sağlığı ve } \\
\text { Güvenliğine } \\
\text { Yönelik Tutum }\end{array}$} & Lise & 3 & 4,778 & 0,385 & \multirow{4}{*}{0,593} \\
\hline & Yüksek Okul & 6 & 4,222 & 0,655 & \\
\hline & Ön Lisans/ Lisans & 49 & 4,429 & 0,704 & \\
\hline & Yüksek Lisans & 21 & 4,286 & 0,701 & \\
\hline \multirow{2}{*}{$\begin{array}{l}\text { İş Sağlığı ve } \\
\text { Güvenliği }\end{array}$} & Lise & 3 & 3,833 & 0,764 & \multirow{4}{*}{0,691} \\
\hline & Yüksek Okul & 6 & 3,333 & 0,683 & \\
\hline \multirow{2}{*}{$\begin{array}{c}\text { Davranışına } \\
\text { Yönelik } \\
\text { Algılanan } \\
\text { Kontrol }\end{array}$} & Ön Lisans/ Lisans & 48 & 3,646 & 0,844 & \\
\hline & Yüksek Lisans & 21 & 3,762 & 0,752 & \\
\hline \multirow{4}{*}{$\begin{array}{c}\text { Güvenliğe Uyum } \\
\text { Davranışı }\end{array}$} & Lise & 3 & 4,111 & 0,192 & \multirow{4}{*}{0,782} \\
\hline & Yüksek Okul & 6 & 3,333 & 0,843 & \\
\hline & Ön Lisans/ Lisans & 48 & 3,611 & 1,109 & \\
\hline & Yüksek Lisans & 21 & 3,571 & 1,076 & \\
\hline \multirow{4}{*}{$\begin{array}{c}\text { Önleyici } \\
\text { Güvenlik } \\
\text { Davranışı }\end{array}$} & Lise & 3 & 4,222 & 0,385 & \multirow{4}{*}{0,58} \\
\hline & Yüksek Okul & 6 & 3,444 & 0,779 & \\
\hline & Ön Lisans/ Lisans & 48 & 3,396 & 1,080 & \\
\hline & Yüksek Lisans & 21 & 3,508 & 0,904 & \\
\hline
\end{tabular}

Tablo 8'de katılımcıların güvenlik iklimi algılarının medeni durumlarına göre değişim gösterip göstermediğine yönelik gerçekleştirilen T-testi sonuçlarına yer verilmiştir.

Tablo 8. Katılımcıların Güvenlik İklimi Algılarının Medeni Durumlarına Göre Farkları

\begin{tabular}{|c|l|c|c|c|c|c|}
\cline { 3 - 7 } \multicolumn{2}{c|}{} & N & Ortalama & Std. Sapma & t & p \\
\hline $\begin{array}{c}\text { Örgütsel } \\
\text { Güvenlik } \\
\text { İklimi }\end{array}$ & Bekar & 41 & 3,764 & 0,8 & \multirow{2}{*}{$-0,782$} & \multirow{2}{*}{0,436} \\
\cline { 2 - 7 } & Evli & 38 & 3,886 & 0,549 & & \\
\hline
\end{tabular}

Buna göre medeni durumlarına göre çalışanların örgütsel güvenlik iklimi alg1 ortalamaları birbirine yakın tespit edilmiş ve $(p>0,5)$ olduğundan H3 kabul edilmemiştir. 
Tablo 9'da ise katılımcıların örgütsel güvenlik iklimi alt boyutlarıyla ilişkili algılarının medeni hallerine göre farklılık gösterip göstermediğine yönelik gerçekleştirilen T-testi sonuçlarına yer verilmiştir. Buna göre örgütsel güvenlik iklimi alt boyutlarından hiçbirine dair algının, çalışanların medeni durumlarına göre değişim göstermediği tespit edilmiştir.

Tablo 9. Katılımcıların Örgütsel Güvenlik İklimi Alt Boyutları İle İlgili Algılarının Medeni Durumlarına Göre Farkları

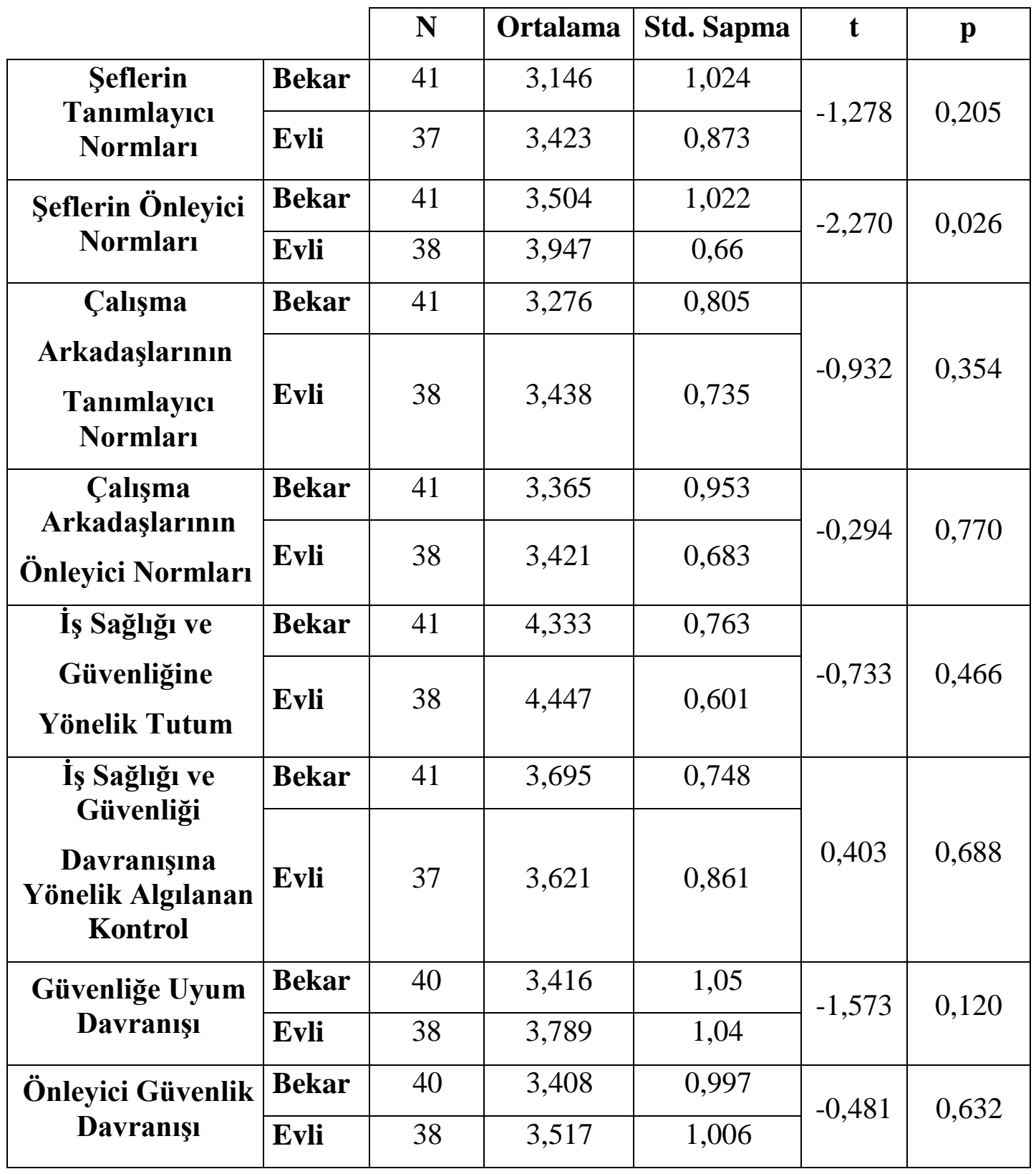

Tablo 10'da katılımcıların örgütsel güvenlik iklimi algılarının çalıştıkları sektöre göre farklılık içerip içermediğine yönelik gerçekleştirilen Anova testi sonuçlarına yer verilmiştir.

Tablo 10. Katılımcıların Güvenlik İklimi Algılarının Çalıştıkları Sektörlerine Göre Farkları

\begin{tabular}{|l|l|l|l|}
\hline $\mathbf{N}$ & Ortalama & Std. & p \\
\hline
\end{tabular}




\begin{tabular}{|c|l|c|c|c|c|}
\cline { 2 - 5 } \multicolumn{2}{c|}{} & & & Sapma & \\
\hline $\begin{array}{c}\text { Örgütsel } \\
\text { Güvenlik } \\
\text { İklimi }\end{array}$ & Özel & 62 & 3,927 & 0,612 & \multirow{2}{*}{0,009} \\
\cline { 2 - 5 } & Kamu & 17 & 3,441 & 0,833 & \\
\hline
\end{tabular}

Buna göre özel ve kamu sektörü çalışanlarının ortalamaları birbirine yakın görünse de $(p<0,05)$ koşulunun sağlanmasından yola çıkarak H4'ün kabul edildiği söylenebilir. Tablo 11'de katılımcıların örgütsel güvenlik iklimi alt boyutlarıyla ilişkili algılarının bulundukları sektöre göre farklılık içerip içermediğine yönelik gerçekleştirilen Anova testi sonuçlarına yer verilmiştir. Buna göre katılımcıların bulundukları sektöre göre algılarının değişim gösterdiği güvenlik iklimi alt boyutlar; şeflerin önleyici normları, iş sağlı̆̆ ve güvenliğine yönelik tutum, iş sağlığı ve güvenliği davranışına yönelik algılanan kontrol ve güvenliğe uyum davranışı olarak belirlenmiştir.

Tablo 11. Katılımcıların Örgütsel Güvenlik İklimi Alt Boyutları İle İlgili Algılarının Sektörlerine Göre Farkları

\begin{tabular}{|c|c|c|c|c|c|}
\hline & & $\mathbf{N}$ & Ortalama & Std. Sapma & $\mathbf{p}$ \\
\hline \multirow{2}{*}{$\begin{array}{c}\text { Şeflerin Tanımlayıcı } \\
\text { Normları }\end{array}$} & Özel & 62 & 3,323 & 0,911 & \multirow{2}{*}{0,421} \\
\hline & Kamu & 16 & 3,104 & 1,146 & \\
\hline \multirow{2}{*}{$\begin{array}{l}\text { Şeflerin Önleyici } \\
\text { Normları }\end{array}$} & Özel & 62 & 3,828 & 0,779 & \multirow{2}{*}{$\mathbf{0 , 0 3 4}$} \\
\hline & Kamu & 17 & 3,314 & 1,152 & \\
\hline \multirow{2}{*}{$\begin{array}{l}\text { Çalışma Arkadaşlarının } \\
\text { Tanımlayıcı Normları }\end{array}$} & Özel & 62 & 3,430 & 0,740 & \multirow{2}{*}{0,096} \\
\hline & Kamu & 17 & 3,078 & 0,846 & \\
\hline \multirow{2}{*}{$\begin{array}{c}\text { Çalışma Arkadaşlarının } \\
\text { Önleyici Normları }\end{array}$} & Özel & 62 & 3,479 & 0,758 & \multirow{2}{*}{0,078} \\
\hline & Kamu & 17 & 3,078 & 1,017 & \\
\hline \multirow{2}{*}{$\begin{array}{c}\text { İş Sağlığı ve Güvenliğgine } \\
\text { Yönelik Tutum }\end{array}$} & Özel & 62 & 4,500 & 0,627 & \multirow{2}{*}{0,005} \\
\hline & Kamu & 17 & 3,980 & 0,768 & \\
\hline \multirow{2}{*}{$\begin{array}{c}\text { İş Sağlığı ve Güvenliği } \\
\text { Davranışına Yönelik } \\
\text { Algılanan Kontrol }\end{array}$} & Özel & 62 & 3,790 & 0,727 & \multirow[b]{2}{*}{0,004} \\
\hline & Kamu & 16 & 3,156 & 0,889 & \\
\hline \multirow{2}{*}{$\begin{array}{l}\text { Güvenliğe Uyum } \\
\text { Davranışı }\end{array}$} & Özel & 61 & 3,765 & 0,980 & \multirow{2}{*}{0,007} \\
\hline & Kamu & 17 & 3,000 & 1,130 & \\
\hline Önleyici Güvenlik & Özel & 61 & 3,557 & 0,942 & 0,108 \\
\hline
\end{tabular}




\begin{tabular}{|l|l|l|l|l|}
\cline { 2 - 4 } Davranışı & Kamu & 17 & 3,118 & 1,136 \\
\hline
\end{tabular}

Tablo 12.'de katılımcıların güvenlik iklimi algılarının çalışma biçimlerine göre farklılık gösterip göstermediğine yönelik gerçekleştirilen Anova testi sonuçlarına yer verilmişstir.

Tablo 12. Katılımcıların Güvenlik İklimi Algılarının Çalışma Şekillerine Göre Farkları

\begin{tabular}{|c|l|c|c|c|c|}
\cline { 3 - 5 } \multicolumn{2}{c|}{} & $\mathbf{N}$ & Ortalama & Std. Sapma & \multirow{2}{*}{$\mathbf{p}$} \\
\hline \multirow{2}{*}{$\begin{array}{c}\text { Örgütsel } \\
\begin{array}{c}\text { Güvenlik } \\
\text { İklimi }\end{array}\end{array}$} & Gündüz & 72 & 3,868 & 0,653 & \multirow{2}{*}{$\mathbf{0 , 0 0 4}$} \\
\cline { 2 - 5 } & Vardiyalı & 5 & 3,800 & 0,628 & \\
\cline { 2 - 5 } & Gece & 2 & 2,250 & 0,354 & \\
\hline
\end{tabular}

Buna göre yalnızca gece çalışan katılımcıların ortalamaları sadece gündüz ve vardiyalı çalışanlara göre daha düşük tespit edilmiştir. İlave olarak $(p<0,004)$ koşulu sağlandığından H5 kabul edilmiştir. Tablo 13'de katılımcıların örgütsel güvenlik iklimi alt boyutlarına dair algılarının çalışma biçimlerine göre değişim gösterip göstermediğine dair gerçekleştirilen Anova testi sonuçlarına yer verilmiştir. Buna göre örgütsel güvenlik iklimi alt boyutlarının tamamına dair algının çalışma şekillerine göre farklılık içerdiği tespit edilmiştir. Çalışanların çalışma şekilleri örgütsel güvenlik iklimi ve alt boyutlarının algılanışına doğrudan etkide bulunmaktadır.

Tablo 13. Katılımcıların Örgütsel Güvenlik İklimi Alt Boyutları ile İlgili Algılarının Çalışma Şekillerine Göre Farkları

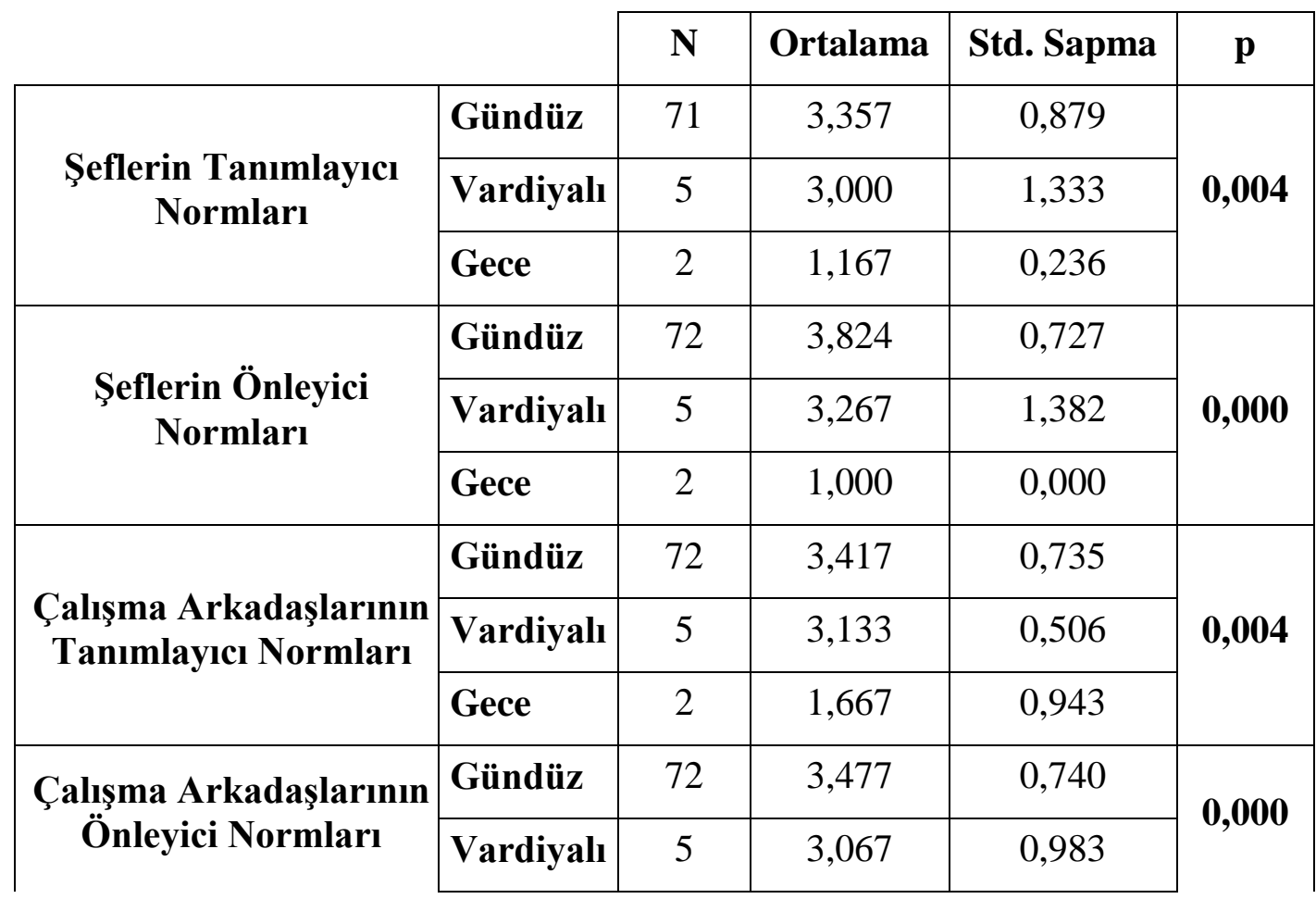




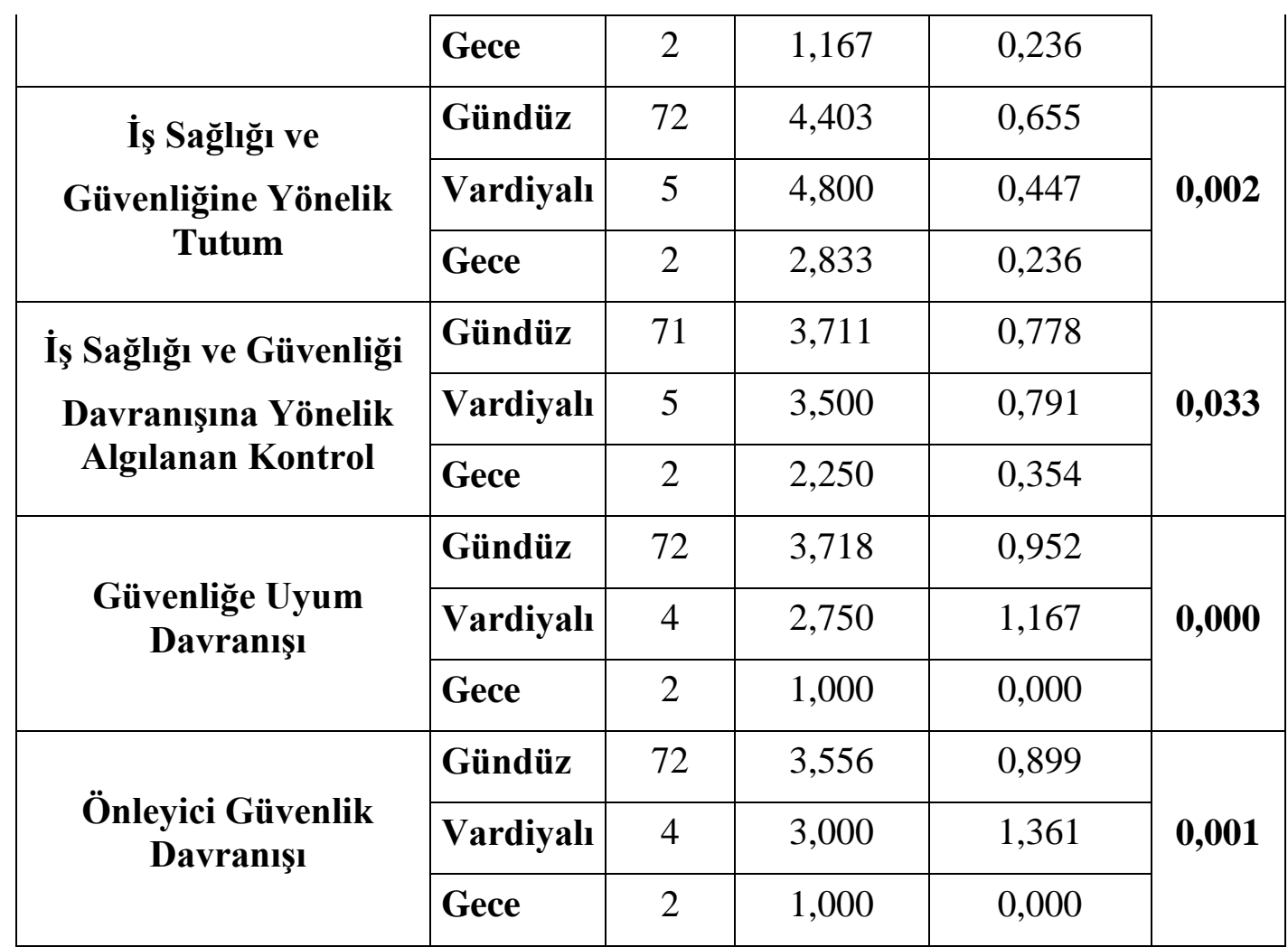

Tablo 14'de hipotezlerin kabul edilme ya da reddedilme durumlarını gösterilmiştir.

Tablo 14. Hipotezlerin Kabul Ret Durumu

\begin{tabular}{|l|c|}
\hline Hipotezler & $\begin{array}{c}\text { Kabul } \\
\text { Durumu }\end{array}$ \\
\hline $\begin{array}{l}\text { H1: İnşaat sektöründe görev yapan çalışanların } \\
\text { güvenlik iklimi algıları cinsiyete göre farklılık } \\
\text { gösterir. }\end{array}$ & Ret \\
\hline $\begin{array}{l}\text { H2: İnşaat sektöründe görev yapan çalışanların } \\
\text { güvenlik iklimi alg1ları eğitim düzeyine göre } \\
\text { farklılık gösterir. }\end{array}$ & Ret \\
\hline $\begin{array}{l}\text { H3: İnşaat sektöründe görev yapan çalışanların } \\
\text { güvenlik iklimi algıları medeni durumlarına göre } \\
\text { farklılık gösterir. }\end{array}$ & Ret \\
\hline $\begin{array}{l}\text { H4: İnşaat sektöründe görev yapan çalışanların } \\
\text { güvenlik iklimi algıları çalıştıkları sektöre göre } \\
\text { farklılık gösterir. }\end{array}$ & Kabul \\
\hline $\begin{array}{l}\text { H5: İnşaat sektöründe görev yapan çalışanların } \\
\text { güvenlik iklimi algıları çalışma durumlarına göre } \\
\text { farklılık gösterir. }\end{array}$ & Kabul \\
\hline
\end{tabular}


Araştırmada test edilen hipotezlerin kabul/ret durumlarından hareketle, araştırmanın başında çizilen model güncellenerek son haline getirilmiştir. Buna gore; cinsiyet, eğitim düzeyi ve medeni durum değişkenleri güvenlik iklimi algısını etkilemediğinden ötürü kesik çizgiler ile gösterilmiştir. Buna karşın güvenlik iklimi algısına etki etmesinden dolayı çalışılan sektör ve çalışma şekli değişkenleri düz çizgi ile gösterilmiştir.

\section{SONUÇ VE TARTIŞMA}

$\mathrm{Bu}$ çalışmada inşaat sektöründe çalışan kişilerin iş sağlığı ve güvenliği algıları kısaca güvenlik iklimi algıları konu edinilmiştir. Bu doğrultuda öncelikle örgüt kültürü, örgüt iklimi, güvenlik iklimi ve benzeri kavramlar açıklanmıştır. Araştırmada, güvenlik iklimi, şeflerin ve iş arkadaşlarının güvenliğe dair normları, güvenliğe yönelik sergilenen tutum, güvenliğe yönelik algılanan davranışsal kontrol algıları ve dolaylı olan ilişkileri görebilmek amacıyla demografik özelliklere göre farklılaşıp farklılaşmadığı sorusuna yanıt aranmıştır.

Çalışma süresince elde edilen bulgulara göre; örgütsel güvenlik iklimi algısının düşük olacağına yönelik analizler sonucu katılımcıların örgütsel güvenlik iklimi algısı 3,82 ortalama ile orta derecede tespit edilmiştir. Dolayısıyla araştırmaya dahil olan katılımcıların olumlu yönde güvenlik iklimi algıları olduğu söylenebilir ve bu algının onların çalışma alanlarında daha dikkatli davranmalarını sağlayacağı yorumu getirilebilir.

Güvenlik iklimi algısı ile çalışanların cinsiyeti, eğitim seviyeleri, medeni halleri, çalışılan sektör ve çalışma şekli arasındaki ilişki incelendiğinde; sektör ve çalışma şekilleri haricindeki değişkenlerin güvenlik iklimi algısında farklılaşmaya neden olmadığı görülür. Çalışılan sektör ve güvenlik iklimi algısı ilişkisine bakıldığında özel sektör çalışanlarının ortalamasının $(3,927)$ daha yüksek olduğu tespit edilmiştir. Özel sektör çalışanlarının güvenlik iklimi algılarının daha yüksek olması, özel kurumların çalışma koşulları hususunda daha olumlu olduklarına işaret etmektedir. Ayrıca özel sektörde yeralan işletmelerdeki güvenlik iklimi algısının örgüt iklimi ile örtüştüğü ve örgütlerin bu yönde çalışmalar ile söz konusu algının gelişimine destek oldukları söylenebilir.

Çalışanların mesailerini sürdürdükleri zaman dilimlerinin de güvenlik iklimi algısına etki ettiği görülmüştür. Gündüz çalışan kişilerin en yüksek ortalamaya $(3,868)$ sahip olduğu, bunu değişken vardiyası olan kişilerin izlediği $(3,800)$ ve en düşük algının ise gece çalışan kişilerde $(2,250)$ olduğu tespit edilmiştir. Gece çalışan kişilerin daha az çalışma arkadaşı ile sosyalleşmeden yoksun olarak işini sürdürmesi, örgütsel güvenlik ikimi algısında çalışma arkadaşlarının rolünün azalmasına neden olabilecek ve bu nedenle de çalışanların algılarında düşüş yaşanabilir. Bu bulgudan hareketle örgütlerin çalışma saatlerini düzenleyerek olumsuz güvenlik algısının önüne geçebileceği düşünülebilir. Elde edilen sonuçlar, güvenlik algısının çalışanların demografik özelliklerinden ziyade örgütün sunmakta olduğu güvenlik seviyesi ile ilişkili görülmüştür. Bunun yanında çalışma koşullarındaki (vardiya gibi) değişimlerin çalışanların güvenlik algısına etki ettiği görülmüştür.

Araştırmamızın temel varsayımını destekleyen Alan Teorisi çevre değişkenlerini açıklamaya odaklanmaktadır. Bunun yanında davranışın insan ve çevrenin bir fonksiyonu olduğunu öne sürmektedir (Aydoğan, 2004). Araştırmanın bulguları kuramsal bağlamı desteklemektedir. Yazında ortaya çıkan araştırmalar güvenlik iklimi ile ilgili bulgularımızı destekler niteliktedir. Araştırmalar farklı ülke bağlamlarında ancak inşaat sektöründe gerçekleşmiştir. 
Araştırmacılar güvenlik ikliminin, temel güvenlik kültürünün özelliklerinin ana hatları olarak görev yaptığını ve güvenlikle ilgili sorunlara ilişkin uyarılar sunduğunu ortya akoymuştur. Gao ve diğerleri 2016 yılındaki çalışmasında, uluslararası inşaat projelerinde güvenlik iklimi bilgilerini araştırmayı ve uluslararası bir bağlamda güvenlik iklimi algılarını etkileyen belirli faktörleri bulmayı amaçlamaktadır. Çinli uluslararası müteahhitler tarafından sözleşme imzalanan beş şantiyede bir anket çalışması yapıldı. Hiyerarşik lojistik regresyon analizi istihdam tarzının, farklı ortamlardan gelen güvenlik iklimi algılarını önemli ölçüde etkileyebileceğini ortaya koymaktadır. Araştırma bulgularına göre taşeronlar tarafından istihdam edilen işçiler, doğrudan ana yüklenici tarafından istihdam edilenlerden daha fazla güvenli iklim algısına sahiptir. Bulgular, uygulayıcıların uluslararası inşaat projelerinde güvenlik performansını artırmak için olumlu bir güvenlik kültürü oluşturmasını sağlayan, güvenlik ortamını etkileyen kritik faktörleri tanımlamaktadır.

Araştırmada gerçekleştirilen literatür tarama ve uygulama kısımlarından elde edilen bulgular nihayetinde iş sağlı̆̆ ve güvenliğini sağlamada örgütün kendisinin ve yönetim kademesinin belirleyici olacağını belirtmek gerekir. Çalışma koşullarının iyileşmesiyle olumlu yönde değişim gösteren güvenlik iklimi algısının, çalışanların şahsi nitelikleri ile doğrudan ilişkili olmadığ 1 düşünülebilir. $\mathrm{Bu}$ durumda işletmelerin çalışanlarını güçlendirmek ve bilinçlendirmek için periyodik eğitim programları düzenlemeleri, denetim ve incelemelerini sürekli hale getirmeleri, işletme büyüklüğüne göre sağlık ve güvenlik birimleri oluşturmaları tavsiye edilebilir. Zira iş sağlığı ve güvenliği hususunda, çalışan algısının olumlu yöne dönüşümü ancak işletmelerin tepeden başlayarak konuyu önemsemesi ve dönüşümü ilk başta kendilerinde gerçekleştirmeleriyle olanaklı hale gelecektir.

\section{KAYNAKÇA}

Akbaba, Ö. (2016). Değişim mühendisliği, örgüt iklimi ve psikolojik sermayenin firma performansı üzerine etkisi. (Yayımlanmamış Yüksek Lisans Tezi), Beykent Üniversitesi Sosyal Bilimler Enstitüsü, İstanbul.

Akkaş, Z.Z. (2006). Türkiye'de yapı üretiminde işçi sağlığı ve iş güvenliği çalışmalar ve toplu konut sektörüne yönelik bir araştırma. (Yayımlanmamış Yüksek Lisans Tezi), Gebze Yüksek Teknoloji Enstitüsü Mühendislik ve Fen Bilimleri Enstitüsü, Kocaeli.

Avcı, C. (2014). İşgörenlerin iş sağlığı ve güvenliği davranışlarının güvenlik iklimi ve planlı davranış kuramı kapsamında incelenmesi: konaklama işletmelerinin yiyecekiçecek departmanlarında bir uygulama. (Yayımlanmamış Yüksek Lisans Tezi), Gazi Üniversitesi Sosyal Bilimler Enstitüsü, Ankara.

Aydoğan, Z. F. (2004). Örgüt kültürü ve iklimi. Gazi Üniversitesi Ticaret ve Turizm Ĕ̆itim Fakültesi Dergisi, 2, 203-215.

Büyükkışlalı, B. (2015). Çalışanların örgüt kültütü algısının ağ (şebeke) tipi organizasyonlarda incelenmesi. (Yayımlanmamış Yüksek Lisans Tezi), Gazi Üniversitesi Eğitim Bilimleri Enstitüsü, Ankara.

Başkaya, R. (2014). Örgüt ikliminin çalışan performansı üzerine etkisi ve bir uygulama. (Yayımlanmamış Yüksek Lisans Tezi), Beykent Üniversitesi Sosyal Bilimler Enstitüsü, İstanbul. 
Baradan, S. (2006). Türkiye inşaat sektöründe iş güvenliğinin yeri ve gelişmiş ülkelerle kıyaslanması. DEÜ Mühendislik Fakültesi Fen ve Mühendislik Dergisi, 8(1), 87100.

Çiftçi, K. (2014). İlkokul öğretmenlerinin örgüt iklimine ilişkin algılarının örgütsel güven üzerindeki etkisi. (Yayımlanmamış Yüksek Lisans Tezi), Zirve Üniversitesi Sosyal Bilimler Enstitüsü, Gaziantep.

Ersan, Z.E. (2014). Yeni iş sağlı̆̆1 ve güvenliği kanununun işletmelerde güvenlik iklimine etkisi ve alan araştırması. (Yayımlanmamış Yüksek Lisans Tezi), İstanbul Üniversitesi Sosyal Bilimler Enstitüsü, İstanbul.

Gao, R., Chan, A. P. C., Utama, W. P. ve Khan, H. Z. A. (2016). Workers' perceptions of safety climate in international construction projects: effects of nationality, religious belief, and employment mode. Journal of Construction Engineering and Management 143(4):04016117.

Gül, A. (2015). Sağlık çalışanlarında örgüt güvenlik iklimi ve çalışan güvenliği arasındaki ilişkinin incelenmesi. (Yayımlanmamış Yüksek Lisans Tezi), Atılım Üniversitesi Sosyal Bilimler Enstitüsü, Ankara.

Külekçi, B. (2012). Gemi inşaatı endüstri çalışanlarının iş sağlığı ve güvenliği algılarının değerlendirilmesine yönelik bir araştırma. (Yayımlanmamış Yüksek Lisans Tezi), İstanbul Üniversitesi Sosyal Bilimler Enstitüsü, İstanbul.

Kızgın, M.A. (2017). İnşaat işçilerinin yüksekte çalışmaları ve kullanılan iskelelerin iş sağlığı ve güvenliği risklerine etkisi. (Yayımlanmamış Yüksek Lisans Tezi), Üsküdar Üniversitesi Sağlık Bilimleri Enstitüsü, İstanbul.

Karadağ, E.S. (2010). Türk inşaat sektörünün iş güvenliği açısından risk analizi. (Yayımlanmamış Yüksek Lisans Tezi), Ege Üniversitesi Sosyal Bilimler Üniversitesi, İzmir.

Karaosmanoğlu, F. (2016). İnşaat projelerinin iş sağlığı ve güvenliği performasının sözleşme ve sözleşmesel düzenlemeler aracılığı ile arttırılmasına yönelik bir inceleme. (Yayımlanmamış Yüksek Lisans Tezi), İTÜ Fen Bilimleri Enstitüsü. İstanbul.

Koç, M.B. (2016). İnşaat sektöründe çalışanların güvenlik iklimleri ile ilgili algıları, (Yayımlanmamış Yüksek Lisans Tezi), Çankaya Üniversitesi Sosyal Bilimler Enstitüsü, Ankara.

Obuz, S. (2016). İnşaat sektöründe çalışanların iş sağlığı ve güvenliği hakkındaki bilgi düzeyleri. (Yayımlanmamış Yüksek Lisans Tezi), İ. Yeni Yüzyıl Üniversitesi Sağlık Bilimleri Enstitüsü, İstanbul.

Özaslan, B.Ö. (2011). İş sağlı̆̆1 ve güvenliği yönetim sistemi ve lojistik sektöründe faaliyet gösteren işletmelerde bir araştırma. (Yayımlanmamış Yüksek Lisans Tezi), İstanbul Üniversitesi Sosyal Bilimler Enstitüsü, İstanbul.

Özaslan, B.Ö. ve Tüzüner, V. L. (2011). Hastanelerde iş sağlığ ve güvenliği uygulamalarının değerlendirilmesine yönelik bir araştırma. İstanbul Üniversitesi İşletme Fakültesi Dergisi, 40(2), 138-154.

Özkul, Y. (2013). Örgüt ikliminin motivasyon üzerine etkisi. (Yayımlanmamış Yüksek Lisans Tezi), Marmara Üniversitesi Sosyal Bilimler Enstitüsü, İstanbul. 
Öztürk, F. (2010). Örgüt kültürünün rekabetçi değerler açısından analizi. (Yayımlanmamış Yüksek Lisans Tezi), Abant İzzet Baysal Üniversitesi Sosyal Bilimler Enstitüsü, Bolu.

Sözer, E. (2012). Hasta güvenliği kültürü ve ölçüm yöntemleri. (Yayımlanmamış Yüksek Lisans Tezi), Dokuz Eylül Üniversitesi Sosyal Bilimler Enstitüsü, İzmir.

Tagay, Ö. M. (2010). Gestalt temas engelleri ölçeğinin geliştirilmesi ve üniversite öğrencilerinin temas engellerinin incelenmesi. (Yayımlanmamış Doktora Tezi), Hacettepe Üniversitesi Sosyal Bilimler Enstitüsü, Ankara.

Tekin, A. (2013). İşgören sağlığı ve iş güvenliği kapsamında işyeri güvenliğini sağlamak için verilen yönetsel desteğin incelenmesi üzerine bir araştırma. (Yayımlanmamış Yüksek Lisans Tezi), Marmara Üniversitesi Sosyal Bilimler Enstitüsü, İstanbul.

Temel, C.T. (2017). İnşaat işçilerinin iş sağlığı ve güvenliği konusunda uygulama ve algılama düzeyi. (Yayımlanmamış Yüksek Lisans Tezi), Çukurova Üniversitesi Fen Bilimleri Enstitüsü, Adana.

Türen, U., Gökmen, Y., Tokmak, İ. ve Bekmezci., M. (2014). Güvenlik iklimi ölçeğinin geçerlilik ve güvenilirlik çalışması. Süleyman Demirel Üniversitesi İktisadi ve İdari Bilimler Fakültesi Dergisi, 19(4), 171-190.

Uslu, V. (2014). İşletmelerde iş güvenliği performansı ve iş güvenliği kültürü algılamaları arasındaki ilişki. (Yayımlanmamış Yüksek Lisans Tezi), Eskişehir Osmangazi Üniversitesi, Eskişehir.

Yüceler, A. (2009). Örgütsel bağlılık ve örgüt iklimi ilişkisi: teorik ve uygulamalı bir çalışma. Selçuk Üniversitesi Sosyal Bilimler Enstitüsü Dergisi, 22, 446-449. 